Article

\title{
Education for Sustainable Development Goals (ESDG): What Is Wrong with ESDGs, and What Can We Do Better?
}

\author{
Helen Kopnina \\ International Business, The Hague University of Applied Sciences, 2521 EN The Hague, The Netherlands; \\ h.kopnina@hhs.nl
}

Received: 3 September 2020; Accepted: 21 September 2020; Published: 23 September 2020

\begin{abstract}
This article will discuss social, environmental, and ecological justice in education for sustainable development (ESD) and Education for Sustainable Development Goals (ESDG). The concept of sustainable development and, by extension, the ESD, places heavy emphasis on the economic and social aspects of sustainability. However, the ESD falls short of recognizing ecological justice, or recognition that nonhumans also have a right to exist and flourish. An intervention in the form of an undergraduate course titled Politics, Business, and Environment (PBE) will be discussed. As part of this course, students were asked to reflect on the three pillars of sustainable development: society, economy, and environment, linking these to the fourth concept, ecological justice or biospheric egalitarianism. Biospheric egalitarianism is characterized by the recognition of intrinsic value in the environment and is defined as concern about justice for the environment. Some of the resulting exam answers are analyzed, demonstrating students' ability to recognize the moral and pragmatic limitations of the anthropocentric approach to justice. This analysis presents ways forward in thinking about the role of "ecological justice" as the ultimate bottom line upon which both society and economy are based.
\end{abstract}

Keywords: biospheric egalitarianism; ecological justice; education for sustainable development; environmental justice; sustainable development

\section{Introduction}

This article questions the Education for Sustainable Development Goals (ESDG) through the lens of critical theory and ecopedagogy. Critical theory was developed, among others, by Ivan Illich (1926-2002), a polymath and teacher; Erich Fromm (1900-1980), a Marxist psychoanalyst and philosopher; and by Paulo Freire (1921-1997), Brazilian neo-Marxist educator. Illich [1,2] fixes attention on the oppressive structure of institutionalized education, describing it as stringent and hegemonic. Fromm [3,4] believed that education makes learners internalize the alienation inherent in capitalist society and increases uncritical adherence to the dominant values espoused in these societies. To oppose uncritical adherence to dominant ideology, an educator is required "to stick to one's convictions even though they are unpopular" [3,4]. To do what was right, one had to call forth "the courage to judge certain values as of ultimate concern - and to take the jump and stake everything on these values" [3,4]. In his Pedagogy of the Oppressed, Freire [5] warns that education hardens any idea into a standardized system, thus threatening to become a tool to sustain oppression.

Critical pedagogy was consequently developed to include a clear focus on environmental sustainability by ecopedagogical scholar Richard Kahn [6]. Kahn noted that the issue of social justice and economic inequality is often placed to the fore of educational agendas, while ecological injustice in the form of discrimination against nonhuman species is hardly addressed. Similar to 
critical pedagogists, Kahn sees education as a form dominating bureaucracy that annihilates creativity. Kahn discusses this annihilation based on Fromm's and Freire's work in the context of modern capitalist society and sustainable development discourse. This discourse nestles within the pedagogy of "technoliteracy", delimited in terms of computer-based vocational education, such as business education, which will be discussed in this article [6].

While critical of "capitalism" in pedagogical practice, Kahn has identified reliance on technical fixes, industrial development and anthropocentrism as the key obstacles to true liberation, not just for oppressed learners but for other species [6]. Ecological pedagogy or ecopedagogy points out that biospheric egalitarianism, the view that there is an intrinsic value to all living beings, regardless of their instrumental utility [7], is rarely taught. This ecopedagogical critique is based on the distinction between anthropocentrism and ecocentrism [7]. The term ecocentrism, or ecology- or ecosystem-centredness, derives from the concept of "deep ecology" [7], which recognizes the intrinsic value of nonhuman beings and supports ecological justice in conservation [8-10] and education [11-14]. By contrast, anthropocentrism, or human-centredness, refers to the interests that are not just centered on a single (human species) but simultaneously excuse moral, political, or legal concern with nonhuman beings [15].

More recently, this criticism has turned toward Sustainable Development Goals (SDGs), seventeen goals primarily addressing social and economic development [16]. The criticism concerns the oxymoronic aims of SDGs and Education for Sustainable Development Goals, or ESDG. For example, when the first two aims of the SDGs, eliminating poverty and hunger, are addressed, "inclusive and sustainable economic growth" is highlighted as a solution for sustainability challenges. However, continuous (and "sustained" in a sense of continuing to perpetuity) economic growth is likely to result in increased consumption of natural resources, thus exacerbating environmental crises [17]. As Haydn Washington [18], an environmental scientist has stated, sustainability is not the same as sustainable development. 'Sustainability' refers not just to natural resources but to the lives and flourishing of all beings on a finite planet, while 'development' typically refers to industry and economy. Growth fueled by demand for resources exacerbates environmental crises though overproduction, overconsumption and overpopulation [18]. Environmental crisis, in turn, is likely to affect the long-term social and economic development [18]. It was noted that UNESCO's Teaching and Learning for a Sustainable Future program essentially stresses social and economic priorities with the exclusion of eco-philosophical principles [11].

This article will compare and contrast ecopedagogy with education for sustainable development and education for ESDGs. This comparison will be based on a critical scholarship that has exposed sustainable development's hegemonic tendencies that influence both practice (policy) and underlying ethics (morals) [19-24]. Sustainable development, according to critical educational scholars, reflects "highly anthropocentric and economist motives that lead to nature being seen essentially as a resource" [19] (p. 710).

This article questions how sustainable development discourse, the SDGs, and ESDG fail to address the ideology of prioritizing economic growth, continuing industrial production, and anthropocentrism [17]. While the SDGs are presented as largely democratic and inclusive, the goals are silent on the subject of the representation of non-human species, so the "inclusiveness" only applies to a single species [22]. The challenge of biospheric egalitarianism remains. This leaves a question as to what extent the interests of non-humans should be considered in the decision-making process [25], exposing a problem with ESDG, which favors social and economic justice above biospheric egalitarianism.

To illustrate this problem with an empirical example, the case study of educational intervention will be examined. This intervention involves the undergraduate critical thinking course, part of the Sustainable Business minor, titled Politics, Business, and Environment (PBE). This course was taught by the lecturer and author of this article at The Hague University of Applied Sciences, International Business department, in the spring semester of 2020. As part of this course, international (third year) 
undergraduate students were asked to consider literature, films, and online (due to COVID-19) guest lectures that exposed them to various schools of thought about sustainable development. In their assignments, the students were asked to reflect on the concepts related to the social, economic, and environmental pillars of sustainable development, linking these to "justice".

\section{Critical Pedagogy and Ecopedagogy}

Critical pedagogy, which inspired ecopedagogy, has pointed out that elements of indoctrination are unavoidable in educational practice as all education is based on values [1-4]. Both Fromm and Illich suspect that education creates individuals that appear rational, but in fact, succumb to the consumerist tendencies of the industrialist age. In his Limits to Medicine, Illich [2] is critical of the elites that create an illusion of progress, as in developing medical technologies, while denying the reality of death, pain, and sickness, and thus dehumanizing society.

This reflection is especially relevant in the time of the coronavirus (COVID19) epidemic in 2020. In the effort to stamp out the virus, the massive, resource-intensive machinery is put in place, fueled by concerns of lost productivity due to slowing the economy. The lives of billions of laboratory animals are claimed in order to create a vaccine, while the efficiency of animal-tested medicines on human subjects and the lack of ethical justification for experimentation are disputed [26]. At the institutional level, increasing internal and external research collaborations with scholars may increase the performance of academic institutions [27], but when the efforts of medical scientists and academics are not complimented by educational specialists in ethics or environmental sustainability, this can result in limited progress. In education, as Helena Pedersen [12], a critical animal studies scholar notes, this translates into normalizing animal experimentation as animals are routinely incorporated in the science curriculum, with students taught to "utilize, dominate, or control other species as dissection specimens for hands-on training of certain skills in science classrooms". This type of education, or "technoliteracy" [12] and "scientism" [19], which, in this case, disregards the interests of nonhuman species, is typical of the ESD [12]. Concern for human benefit at the expense of animals is very clear during the pandemic. Simultaneously, the root causes of the pandemic, the growing human population, and an increase in consumption of meat and wildlife trade remain in the background [26]. As Eileen Crist [28] writes:

"By increasing our numbers, locally and globally, and by flouting the population question altogether in mainstream and other circles, humanity has magnified habitat destruction and defaunation, and thus the spread of zoonotic diseases as well ... Eating wild and domestic animals and their products is completely out of kilter with Earth's integrity, animal well-being, and human health" (https://blog.ecologicalcitizen.net/2020/04/22/the-covid-19-mirror/).

The sustainable development rhetoric hardly mentions the questions of human population growth or consumerism, which were raised from the 1960s onwards. Fromm [13] is concerned about the notion of progress that comes at the expense of other values. In The Heart of Man, Fromm [4] writes that he does not believe that Man is either good or evil, but he may become either depending on his relationship with the world. Fromm [13] is explicitly critical of consumerism, not just the elites, but the masses who are influenced by the educational system. According to Fromm, the educational system helps to produce students who can be easily used by the economic system to become perfect consumers. Higher ideals, such as freedom, justice, and unity with nature, are then submerged. Fromm [13] believes that the Man choosing progress can find a new unity through three orientations: biophilia, love for humanity and nature, and independence and freedom.

Both Fromm and Illich warn that the supposedly higher ideals that are taught at schools (and universities) fall short of realizing the real freedom of human spirit and justice. Indeed, Freire [5] speaks of the oppressor consciousness that tends to transform its surroundings, including the earth and artifacts created by laborers, but also people themselves, to the status of objects at its disposal. This oppressor consciousness is not necessarily anthropocentric (or human-interest centered), as David 
Kidner [15] proposed. Rather, this consciousness creates a system that is harmful to both the natural environment and human flourishing. While what Kidner [15] (p. 470) calls the "new symbolic framework based on scientific and economic concepts", it clearly has human origins, redefining the external nature and human beings themselves as objects. In this framework, human beings fit into the new order as cogs in the wheel, and education serves, to return to the term "technoliteracy" [12], as a tool of indoctrination.

Kahn [12] discusses these scientific concepts in the context of education and environmental justice. The common use of the term "environmental justice", apart from the way it is used by Schlosberg [29], refers to social justice. Social justice concerns the distribution of environmental goods (such as natural resources) and harms (such as pollution), presenting "environment" or "nature" in utilitarian terms [30]. By contrast, ecological justice [29-31] is concerned with the moral status of other species, associated with biospheric egalitarianism. Biospheric altruism is a concern with the environment or individual nonhumans independent of their utilitarian use for humans, as discussed by environmental philosophers Arne Naess [7], Paul Taylor [32] and Stan Rowe [33].

However, while education is strongly influenced by hegemonic ideologies-for example, by capitalism or neoliberalism, forms of emancipatory learning are also possible. Translated into educational practice, the guidelines for this education were developed at the 1972 UN Conference on the Human Environment in Stockholm. In 1975, responding to the need to address the environmental issues caused by human activities, the so-called Belgrade charter was produced. It stated:

"The goal of environmental education is to develop a world population that is aware of, and concerned about, the environment and its associated problems, and which has the knowledge, skills, attitudes, motivations, and commitment to work individually and collectively toward solutions of current problems and the prevention of new ones (https://www.gdrc.org/uem/ee/belgrade.html)".

To achieve these objectives, many forms of ecology-centered (or ecocentric) education have emerged [21,23]. Indeed, ecopedagogy is driven by the ideas espoused in the Belgrade charter. Typically, this ecology-centered education included critical studies addressing the root causes of unsustainability, namely the limits to industrial development and population growth [34]. However, earlier initiatives of environmental education to prioritize environmental protection and care while focusing on ecocentric ethics and justice have given way to education for sustainable development. Critics have noted the tendency of educational institutions to embrace, uncritically, education for sustainable development and the SDGs [17]. One of the central concepts encompassed by all 17 SDGs is "sustainable and inclusive economic growth" (https://sustainabledevelopment.un.org/sdgs).

In their article in Harvard Business Review discussing the SDGs and business, Kramer and colleagues [35] asked: "Are companies advancing serious solutions or are they simply embarking on a massive global public relations charade?". A similar question emerged in our case study of (sustainable) business education. Kramer et al. [35] are concerned about the vagueness of SDGs, noting, for example, that SDG 3, "to ensure healthy lives and promote well-being for all" can encompass just about anything. The added concern in this article is the price paid for actually achieving such goals.

Ignoring the robust literature placing economic growth and industrial development at the root of environmental problems [17,36-39], the SDGs bask in naïve or manipulative optimism attempting to successfully combine social, economic and environmental objectives. The SDGs might be focusing on the symptoms of injustice and ignoring the causes, such as the highly imbalanced relationship of people with the natural world, both in terms of ethics (biospheric egalitarianism) and pragmatically, in solving environmental challenges [17]. Thus, instead of seeing the Planet as a basis upon which People can Profit, the triple Ps are seen as perfectly "balanced", with Profit not only unquestioned but seen as essential for achieving some of the SDGs [17]. Population Matters, a charity that focuses on human rights, equality, and sustainability, has emphasized that the SDGs also conspicuously ignore the question of population growth (Source: https://populationmatters.org/urge-un-act-population). See Figure 1. 

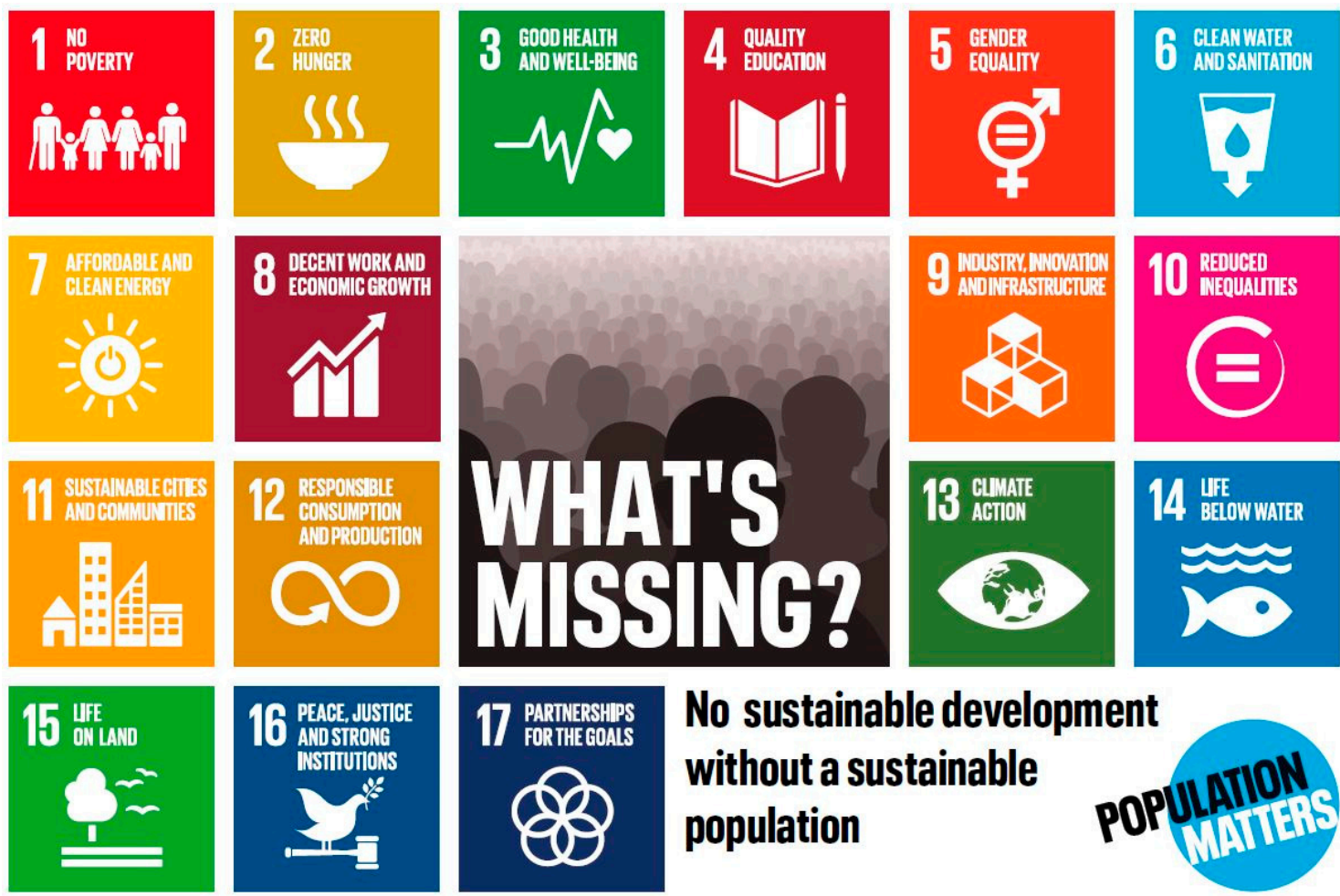

Figure 1. Population matters (Source: https://populationmatters.org/urge-un-act-population).

Thus, in a nutshell, critical examination of sustainable development and SDG rhetoric reveals a strong focus on social and economic issues such as poverty and hunger reduction (the first two of the SDGs), with the environment often discussed as a tool to achieve these ends, as in "sustainable use (sic) of biodiversity" [40]. While poverty alleviation and hunger reduction are certainly worthy causes, the SDG text suggests that both can be achieved through economic means, as well as technological progress, including the intensification of agriculture (https://www.un.org/sustainabledevelopment/ sustainable-development-goals/). This intensification does not consider negative effects such as toxicity, the creation of monocultures that threaten biodiversity, and increasingly poor farm animal welfare [41]. The needs of nonhumans, ecological justice, and biospheric egalitarianism are ignored in SDG's objectives, as "inclusion" is unquestionably assumed to apply only to one species [17]. Even purely anthropocentric objectives are not met, as the destruction of the environment is unlikely to lead to world peace, poverty, and hunger reduction [38]. These tendencies refer to a disjuncture between anthropocentrism of environmental justice proponents with their lofty ideals of equity and equality, and a distinct ferocity in the way these ideas are expressed, amplified by the supporters' humanistic rhetoric. While 'raising the standard of living' may be nebulous shorthand for the worthy aim of ending severe deprivation, it is in effect a euphemism for the global dissemination of consumer culture [37] (p. 141) which will lead to a deepening of the resource crisis for the vulnerable groups [38]. As Adelman [17] has argued, the growth-driven development that the SDGs support is intrinsically ecologically unsustainable because it destroys ecosystems and breaches planetary boundaries in its quest for economic growth. The very term "sustainable development" is oxymoronic "because it erroneously fosters the illusion of combining endless economic growth on a finite planet, social justice, and environmental protection" [17] (p. 14). The SDGs perpetuate an anthropocentric conception of development and sustainability antithetical to effective responses to the rupture of the Earth system [17] (p. 14). 


\section{Education for Sustainable Development Goals (ESDG)}

Returning to Illich [2] and Fromm [3,4], we note that in application to the present-day celebration of SDGs at schools, the supposedly higher ideals fall short of realizing the real freedom of human spirit and justice in favor of more consumerism and short-term thinking. Oblivious to this critique, many (Western) universities seemed to have embraced education for sustainable development goals (ESDG). As Kopnina [22] (p. 8) wrote:

"Perhaps one should not suspect the ESDG as anything as grand as a neoliberal conspiracy or a cunning ploy to maintain the status quo. The rapid spread of the SDG-supporting institutions, including the author's university, is probably due to nothing more sinister than indifferent management, and a dull-minded rehearsal of received "truths" (e.g., the triple bottom line), rather than a serious effort to rein in alternative visions ... Still, it does seem that in our current political and cultural climate, the barrage of immediately urgent economic, social and moral pursuits (racial and gender equality, equal pay, etc.) that progressive Western education strives on, leaves little room for perceivably more distant issues. One of these "back of the mind" issues is the loss of biodiversity, which may not pose an immediate threat to an identifiable group of people (as opposed to other forms of life). The arguably justified attention to the various social upheavals has meant that the failures of environmental policy to address anything from biodiversity loss to climate change is attracting much less criticism than it otherwise would. The more radical, revolutionary, and powerful education for the environment can only be realized if the survival of other species and the long-term consequences of environmental degradation on people are considered not just as one of many issues, but as a priority".

To provide an example as to how an educational program can make environmental integrity a priority, the case study below examines how both cognitive (knowing about the problem) and empowerment (being able to actively address the problem) issues can be addressed. Since critical thinking relies on a non-traditional pedagogy, the course aims to promote behavioral change.

\section{Methodology: A Case Study}

Twenty-six international students of a sustainable business minor, an elective course at the International Business department, have been introduced to social, political, economic, environmental, and ethical topics related to business. The minor consisted of five parts (modules):

1. Politics, Business, and Environment (PBE);

2. Introduction to Sustainable Business;

3. Essay;

4. CSR and Global Supply Chains;

5. Weekly guest speakers from different industries.

The module discussed in this case study is PBE, offered between February and June 2020. PBE links the subjects of business, politics, environmental ethics, sustainability, and economic development. These questions, used to promote critical thinking, were raised in the course: Can poverty reduction be decoupled from economic growth and increase in consumption of natural resources? If the alternative path to economic development cannot be found, how can striving towards a better standard of living avoid potentially catastrophic impacts on the global ecosystem? Since the future generations are not born yet and non-human species cannot speak for themselves, how can they be represented in democratic systems? How can businesses help overcome sustainability challenges?

This module also focuses on considerations of justice, development, resource use, social equality, and biological conservation in the context of sustainable business. The course also considers alternatives to conventional sustainability approaches and ecologically benign models of production. As part of the course, some of the literature named in the introductory section above is discussed. The students are asked to present and actively discuss the literature related to the paradoxes of combining ethics and 
sustainability [41], as well as pragmatic solutions such as degrowth [36], steady-state-economy [39]. This literature is also intertwined with related modules of the minor, for example, the guest speakers and company visits. Some of the guest speakers from non-governmental organizations (NGO's), for example, tell students how businesses can help their charities to function more professionally, reflecting a trend towards a more socially and ecologically involved corporation [42]. Invited NGO's included the World Wide Fund for Nature (WWF), with the speaker presenting a case akin to the ecopedagogical method of active engagement and participation of students in activist organizations. One of the guest speakers in the course described in this case study was Haydn Washington, whose work is cited in the literature list. See Figure 2.

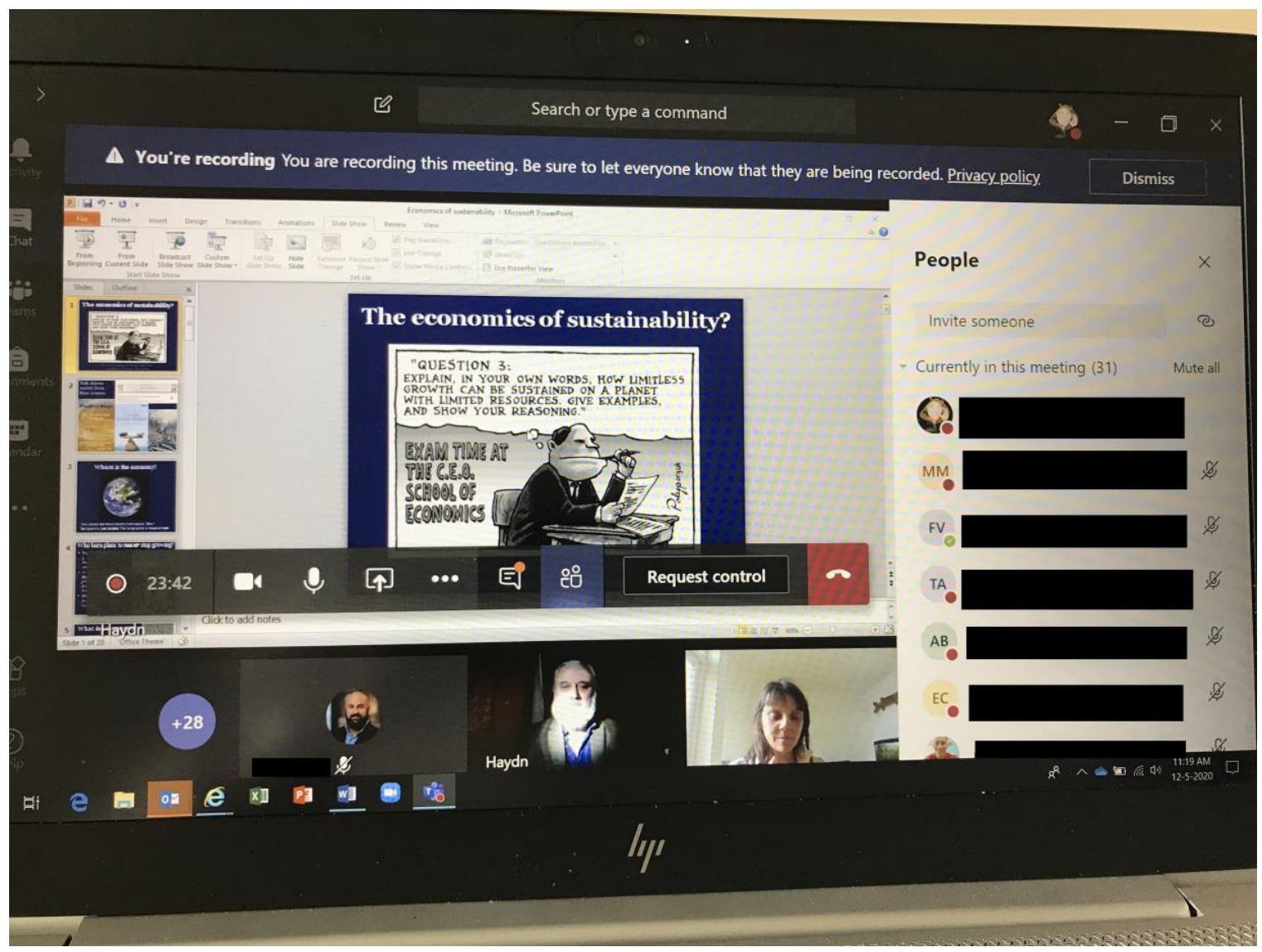

Figure 2. Presentation Haydn Washington "The Economics of Sustainability", 12 May 2020, Copyright: Author.

As part of PBE, the students were asked to engage in debates (the preposition discussed for one of the debates was "Poverty reduction can be decoupled from an increase in consumption of natural resources"). Another full-class activity included a role-play (enacting different stakeholders of Shell, oil company, including the CEOs of the company, shareholders, Dutch and English heads of state, and environmental protestors. This role-play is intended for students to better understand how political, economic, and environmental objectives are weighed). The students were also asked to present their opinions after the debate, discussing assigned articles and films. One of the films shown to students is If A Tree Falls; A Story of the Earth Liberation Front [13]. The film discussion uses ecopedagogical approaches developed by Kahn [12], asking complex questions about the role of society in framing what is seen as normal and as radical.

The empirical segment presented below presents one (out of 10) answers to open questions as part of the PBE exam (worth half of PBE's total grade, with the rest consisting of individual assignments and group presentation). One of the questions was: (A). What is meant by biospheric egalitarianism)? 
(B). What implications does biospheric egalitarianism have for conducting business? An anonymous (although the student's gender and country origin are identified) sample of 9 out of 26 exams was selected randomly based on the time of online submission of the exam.

\section{Student Exam Answers}

\subsection{Swedish Female}

Biospheric egalitarianism simply means taking into account non-human nature. It takes into account the rights of non-human species, regardless of human interest. It moves away from anthropocentrism and towards ecocentrism. One impact of biospheric egalitarianism that some businesses will feel is the respect for animals and their welfare. The meat industry for example will have to fundamentally change its ways by biospheric egalitarianism, reducing mass production of meat and providing animals with better lives. It will require many companies to switch from using animals as mere resources without respecting them, to respecting them and their rights to a good life.

\subsection{Slovakian Female}

Biospheric egalitarianism: considering non-human nature. It concerns the rights of other species independent of human interests. It is considering the value of species we depend on and don't depend on. This is what we define as ecocentrism. A good example of biospheric egalitarianism is the meat and dairy industry, in which case we are contributing to human welfare by producing food for our populations. However, there isn't any thought given to the rights and wants of the animals who are being injected with viruses, experimented on, and killed to benefit human welfare. Animals are slaughtered every day under horrendous conditions without taking the suffering and the rights of these animals. We need to consider the rights of animals apart from only considering our welfare.

\subsection{German Male}

Biospheric egalitarianism concerns the rights of other (non-human) species independently of human interest. For conducting business, biospheric egalitarianism has different implications: Applying biospheric egalitarianism as a business value means to respect ecosystems (i.e., not harvesting a forest to build a factory) or integrating business buildings into nature (i.e., by greening the walls and roofs, so that animals can use it as their habitat). Of course, it also means that businesses should not engage in animal testing and produce products that contain no materials harmful to the environment. But first and foremost, the company's business model has to be clear about biospheric egalitarianism, so that, by its existence, the business contributes towards ecological justice.

\subsection{Mixed Ethnic Background Dutch Male}

Bioshpheric Egalitarianism refers to the rights of non-human species independent of the priorities of humanity. This would include adopting the rights of plant and animal species into existing legal frameworks. Furthermore, it calls on a shift in our perception of non-human species or life as intrinsic and more than resources that fuel humanity's unending expansion. Currently, human supremacy is deeply rooted in all aspects of humanity including our even our linguistics and our interactions with non-human species. It would require a fundamental shift in global thought to recognize the value of non-human life and protect it through the avenues of legal and political enforcement. The ramifications on how business is conducted with Biospheric Egalitarianism are numerous. Primarily, existing businesses that violate the rights of non-human life would need to radically change or more likely die out. For example, will we be still able to consume animals if we fully recognize their intrinsic value? This will affect billions of people's dietary patterns and hundreds of millions of jobs around the world. It would wholly reinvent the parameters of how business is done...

Biospheric egalitarianism is where we see all species as equal to our own and take their welfare into account when we make decisions. It is about the value of animals and plants relating to humans and 
that they have their rights. It can be used for industries where deforestation is a problem as it destroys the habitat and lives of animals. The habitat of animals and their welfare should be taken into account when conducting businesses. Taking the life of animals into account when conducting business.

\subsection{Dutch Male}

Biospheric egalitarianism is the idea that the needs of humanity and all of the environment should be considered and that the environment has its right to also safeguard their future on this planet. Ecocentrism focuses on the benefit of the environment as a whole as opposed to only humanity's benefit. One complication that this could cause for the agricultural industry is that they would have to stop the use of harmful pesticides which cause significant environmental impacts. Although this would reduce the poisoning of wildlife and rivers, it would significantly damage the number of crops that can be yielded.

\subsection{Spanish Male}

Biospheric egalitarianism exposes a love for nature as a total abstract being; it is related to the Gaia hypothesis. Unlike anthropocentrism and biocentrism, ecocentrism is concerned with preserving ecosystems and species, not with preserving the lives of specific individuals. The implications with this are that if you are a business trying to enter the sustainable business industry a great way to sell yourself is to say you are fighting for a biospheric egalitarian world, with the same right for both us and the animals that are the ones that live in the ecosystem that we destroy to build highways or hotels.

\subsection{White Male from Malawi}

Biospheric egalitarianism is concerned with the rights of other species independent of their interactions with humans. Meaning not just pets rights or livestock rights but also those of animals in the wild. When conducting business anthropocentrism is the way of the world, we as humans value human life first. However, this is not to say we will look after human rights as can be seen with many industrial disasters of the past as well as workers' rights in places like China. If we are to take biospheric egalitarianism into account when creating business models it is important to look at the external costs of the business. Is there habitat destruction? Is there pollution? Next, we must look if there are any other things harmed when the good or service is rendered. This may seem obvious but could include things as complicated as seepage killing micro-organisms in surrounding wetlands. I think this is something that not many businesses take into account but is worth considering in developing countries with industries such as agriculture and resource extraction, where huge habitat destruction is likely to occur.

\subsection{German Female}

Biospheric egalitarianism is described as considering and acknowledging the rights and interests of non-human species independently of human interests. It is the opposite of anthropocentrism, which prevails nowadays. So basically it is about turning away from a purely human-centered perspective and considering other species as well. Taking biospheric egalitarianism into account when conducting business, is more and more important. Until now, businesses have operated to generate as much profit as possible, which is logical. But given the environmental circumstances and challenges we are facing increasingly, it is more than clear, that business as usual, where the environment and non-human species are neglected, cannot continue. Attempts such as the triple bottom line have already been established in many companies, leading to an increased focus on the planet, but efforts have to increase. 


\section{Learning from Student Exam Answers: Ways Forward}

The issues discussed by students concerning business and ethics are very diverse, with the following questions raised: "Is there habitat destruction? Is there pollution?" or "things as complicated as seepage killing micro-organisms in surrounding wetlands" and others directly related to animal welfare. One aspect of student learning evident from the assignments is increased awareness of the issues. While it is too early to tell what students intend to do about the issue of ecological injustice (as the effects of learning may take years of "incubation" and multiple influences to develop further), one of the significant aspects discovered at the end of the course was students' eagerness to engage with organizations that prioritized environmental protection. As is discussed above, part of the minor Sustainable Business involves company visits and guest speakers, one of which is Patagonia, an outdoor equipment company that donates some of its profits to biological conservation. Another opportunity was the sustainability department of the ING Bank, which invests in circular economy projects that limit material consumption and waste. Almost one-third of the class expressed interest in applying for an internship for these companies.

The general observation from the exam answers above is that most students realize that biospheric egalitarianism does not mean business as usual. One student notes, for example, that the meat industry "will have to fundamentally change". We note that this claim would require action and radical lifestyle change. A path between reflection and action in the context of this course will yet need to be tested in follow-up longitudinal studies. One way of doing it is through the habitual practice of students to connect to their lecturers via LinkedIn and keep in touch after the course, reflecting on their professional progress. Follow-up interviews with students addressing their (changing or not) attitudes and ability to "live up" to their ideals could be organized for a follow-up study.

Another student reflects that "when conducting business anthropocentrism is the way of the world". Considering the agricultural industry, this student notes that having to "stop the use of harmful pesticides which cause significant environmental impacts" will fundamentally alter the way food is produced. This implies that biospheric egalitarianism will come at a cost and will not be a simple win-win, with one student reflecting that its implementation: "would reduce the poisoning of wildlife and rivers, it would significantly damage the number of crops that can be yielded". Even broader, another student reflects that the application of biospheric egalitarianism "would require a fundamental shift in global thought to recognize the value of non-human life". Another student writes that since "human supremacy is deeply rooted in all aspects of humanity", the shift needs to be radical. Indeed, as this student writes since businesses that "violate the rights of non-human life would need to radically change", this "This will affect billions of people's dietary patterns and hundreds of millions of jobs".

We note that this is not the sacrifice demanded by the more vague and optimistic aims of the SDGs, which focus on balancing the needs of present and future generations (of people). The need for a radical shift is recognized more easily in critical pedagogy and ecopedagogy. Hegemony, in this case, is not just capitalism (or, for that matter, socialism), that anthropocentric status quo. By implication, the task is not just a fantasy of continuing (industrial, agricultural, economic) development by making it sustainable, but of fundamentally shifting the focus towards planetary-wide sustainability. Some examples of such a radical, revolutionary, and powerful education for the environment are embodied by ecopedagogy [12], as discussed in the Introduction. Drawing upon a range of theoretical influences as well as the cognitive praxis produced by today's grassroots (or "radical") activists, such as the Earth Liberation Front and Animal Liberation Front [13], ecopedagogy empowers learners to return to freedom of thought. Ecopedagogy results in emancipatory learning, inspired by civil rights liberation movements, such as, recently, the \#MeToo and \#BlackLivesMatter campaigns. While the answers to the exam presented above by no means reveal a greater potential of the PBE course to engage students in emancipatory learning, they do indicate a direction of continuous educational effort in an attempt to provide justice for human and nonhuman beings. In its effort of making students reflect upon biospheric egalitarianism, which supports the flourishing of all planetary citizens within the multi-species community [24], the ESDG is a far cry from this objective. 
A larger lesson from the course is that students are asked to contemplate a less conventional concept of justice. Rather than a step forward in recognizing injustice towards nonhuman species, SDGs seems to be a step back towards denial. Cohen [43] usefully divides denial into three categories: (1) literal denial (an assertion that something is or is not true), (2) interpretive denial (when facts are not denied but given different interpretations), and (3) implication denial. The latter form of denial is perhaps the most complex as, unlike literal or interpretive denial, knowledge itself is not the issue, but "doing the "right" thing with the knowledge" [43]. This type of denial applies to, for instance, a failure to incorporate knowledge into everyday life and transform it into political action without actually denying an environmental problem (commonly climate change) or its cause. These three types of deniers might argue that it is too late to stop global warming, so we should adopt the idea that warming might be good, or that we must balance climate action with 'concern for the economy' [43]. Within SDGs and ESDG, the denial consists of trying to keep your cake and eating it too-keeping the health of ecosystems intact while feeding an increased population with high material demands. Even a limited sample of student exam answers here shows that some of them have (at least for assessment) developed an ability to problematize, as one student phrases it, "business as usual".

Some students also see (business) opportunities, with biospheric egalitarianism as a clever marketing tool, or as this student puts it, "a great way to sell yourself is to say you are fighting for a biospheric egalitarian world". Another student notes that "given the environmental circumstances and challenges", business as usual cannot continue, and considers ways forward. The possibilities include pragmatic solutions covered in the course, including degrowth [36], steady-state-economy [39], Cradle-to-Cradle, and circular economy [44]. At the institutional level, increasing internal and external research collaborations with scholars devoted to the same subjects can increase not only the scientific performance of academic institutions [27], but also the pedagogical benefits of having a more robust and interconnected critical thinking curriculum. Concretely, this implies connecting both research fields of critical sustainability studies and (environmental) ethics with the pedagogical approaches discussed in the introduction, namely critical pedagogy and ecopedagogy.

Critical pedagogy's and ecopedagogy's focus on environmental sustainability as well as ecological injustice finds expression in a curriculum that critiques "technoliteracy", such as conventional business education, and applies alternatives, as shown in the case study above. As Kahn [12] (p. 62) has expressed, we must seize the "opportunity to critique present-day technopoly". The critical questions raised in the PBE course (and other modules of the minor discussed here) offer suggestions as to how an understanding of key concepts challenging hegemonic assumptions, critical thinking, and alternative models of sustainability can be achieved. By introducing students to select articles and films that differ from conventional sustainable development or SDG approaches, interactive discussions, role play and debate on complex issues such as poverty, resource consumption and social and environmental ethics, the pedagogical benefits of educating critical, active, and engaged citizens come to the fore. This can potentially lead students (and longitudinal follow-up research can delve into this) to substitute the rehearsed slogans of the ESDG (e.g., "inclusive and sustainable economic growth") into transformative understanding and action. This action involves engaging a set of practical solutions, such as thinking of a business and society that can flourish while embracing degrowth, through de-materialization (e.g., using no new materials through leasing rather than ownership), and circular production models that emphasize reuse rather than a waste of resources. Another set of solutions is ethical, having to do with transitioning toward a less anthropocentric mindset—-something that the students of this course might have started to achieve.

\section{Conclusions}

The critical course Politics, Business, and Environment has generated a few significant ideas in business students interested in advancing environmental sustainability. The exam answers presented above are by no means exhaustive of the set of ideas, values, and practical tools that the students of sustainability learn, including the need to transition from the dominant ideology of growth and 
denial through the soothing and vague prescriptions of sustainable development towards a radical change. This transition will not occur after students' writing the exam or completing the course-it is a long process that involves, as the Belgrade charter suggests, both knowledge and motivation. This motivation can potentially initiate behavioral change. The objective of the course described in this article is to help students start this journey. A follow-up longitudinal study that follows students' personal and professional development has the potential to reveal the true extent of lessons learned. In the case of business students, the effects are likely to be revealed through the types of companies or NGOs they will be employed by, and the type of work they will do. Whether this work will be in line with the ideals of biospheric egalitarianism, or more down to earth, with any pragmatic efforts to maintain the ecological integrity of business operations, remains to be seen. However, the seeds of radical, revolutionary education, which is NOT education for sustainable development or SDGs, might have been planted. A modest advancement in student understanding (at least for the period of the exam) of what might be missing from the three supposedly equal pillars of sustainable development, society, economy and environment, and the students' understanding of justice in the form of biospheric egalitarianism are promising. Critical pedagogy and ecopedagogy's call to reform education in such a way that it becomes critical but also emancipated may offer much more than the unreflective quest for economic growth or the optimism of denial espoused by the SDGs.

Funding: This research received no external funding.

Conflicts of Interest: The author declares no conflict of interest.

\section{References}

1. Illich, I. Deschooling Society; Calder and Boyers: London, UK, 1971.

2. Illich, I. Limits to Medicine: Medical Nemesis; Reprint 2010; Marion Boyars Publishers RTD: London, UK, 1975.

3. Fromm, E. The Art of Loving: An Inquiry into the Nature of Love; Harper \& Row: New York, NY, USA, 1956.

4. Fromm, E. The Heart of Man: Its Genius for Good and Evil; Harper \& Row: New York, NY, USA; London, UK, 1964.

5. Freire, P. Pedagogy of the Oppressed; Continuum: New York, NY, USA, 1981.

6. Kahn, R. Critical Pedagogy, Ecoliteracy, and Planetary Crisis: The Ecopedagogy Movement; Peter Lang: New York, NY, USA, 2010.

7. Naess, A. The shallow and the deep: Long-range ecology movement: A summary. Inquiry 1973, 16, 95-99. [CrossRef]

8. Piccolo, J.; Washington, H.; Kopnina, H.; Taylor, B. Back to the future: Why conservation biologists should re-embrace their ecocentric roots. Conserv. Biol. 2018, 32, 959-961. [CrossRef]

9. Washington, H.; Piccolo, J.; Chapron, G.; Gray, J.; Kopnina, H.; Curry, P. Foregrounding ecojustice in conservation. Biol. Conserv. 2018, 228, 367-374. [CrossRef]

10. Taylor, B.; Chapron, G.; Kopnina, H.; Orlikowska, E.; Gray, J.; Piccolo, J. The Need for Ecocentrism in Biodiversity Conservation. Conserv. Biol. 2020. in print. [CrossRef] [PubMed]

11. Molina-Motos, D. Ecophilosophical Principles for an Ecocentric Environmental Education. Educ. Sci. 2019, 9, 37. [CrossRef]

12. Pedersen, H. The Contested Space of Animals in Education: A Response to the "Animal Turn" in Education for Sustainable Development. Educ. Sci. 2019, 9, 211. [CrossRef]

13. Kopnina, H.; Saari, M. If a Tree Falls: Learning active citizenship from environmentalists. Geogr. Educ. 2019, 9, 284.

14. Washington, H. Education for Wonder. Educ. Sci. 2019, 8, 125. [CrossRef]

15. Kidner, D. Why 'Anthropocentrism' Is Not Anthropocentric. Dialect. Anthropol. 2014, 38, 465-480. [CrossRef]

16. UNESCO. Education for Sustainable Development Goals. 2017. Available online: https://www. sdg4education2030.org/education-sustainable-development-goals-learning-objectives-unesco-2017 (accessed on 20 September 2020). 
17. Adelman, S. The sustainable development goals, Anthropocentrism and Neoliberalism. In Sustainable Development Goals: Law, Theory, and Implementation; French, D., Kotzé, L., Eds.; Edward Elgar: Northampton, MA, USA, 2018; pp. 15-40.

18. Washington, H. Is 'sustainability' the same as 'sustainable development'? In Sustainability: Key Issues; Kopnina, H., Shoreman-Ouimet, E., Eds.; Routledge: New York, NY, USA; London, UK, 2015; pp. 359-376.

19. Bonnett, M. Environmental education and the issue of nature. J. Curric. Stud. 2007, 39, 707-721. [CrossRef]

20. Kopnina, H. Education for Sustainable Development (ESD): The turn away from 'environment' in environmental education? Environ. Educ. Res. 2012, 18, 699-717. [CrossRef]

21. Kopnina, H. Ecocentric education. In Encyclopedia of Sustainability in Higher Education; Filho, W.L., Ed.; Springer: Dordrecht, The Netherlands, 2019.

22. Kopnina, H. Education for the Future? Critical Evaluation of Education for Sustainable Development Goals. J. Environ. Educ. 2020, 51, 280-291. [CrossRef]

23. Kopnina, H. Ecocentric Education: Introduction to a Special Collection of Essay. Educ. Sci. 2020, $10,217$. [CrossRef]

24. Spannring, R. Ecological Citizenship Education and the Consumption of Animal Subjectivity. Educ. Sci. 2019, 9, 41. [CrossRef]

25. Lidskog, R.; Elander, I. Addressing climate change democratically: Multi-Level governance, transnational networks, and governmental structures. Sustain. Dev. 2010, 18, 32-41. [CrossRef]

26. Saunders, S. Animal Testing and the Coronavirus Crisis. The Ecologist, 2020. Available online: https: //theecologist.org/2020/apr/16/animal-testing-and-coronavirus-crisis (accessed on 20 September 2020).

27. Aldieri, L.; Kotsemir, M.; Vinci, C.P. The impact of Research Collaboration and Academic Performance: An empirical Analysis for Some European Countries. Socio-Econ. Plan. Sci. 2018, 62, 13-30. [CrossRef]

28. Crist, E. COVID-19 Mirror. Earth Tongues. 2020. Available online: https://blog.ecologicalcitizen.net/2020/04/ 22/the-covid-19-mirror/ (accessed on 20 September 2020).

29. Schlosberg, D. Defining Environmental Justice: Theories, Movements, and Nature; Oxford University Press: Oxford, UK, 2007.

30. Kopnina, H. Environmental justice and biospheric egalitarianism: Reflecting on a normative-philosophical view of the human-nature relationship. Earth Perspect. 2014, 1, 8. [CrossRef]

31. Baxter, B. A Theory of Ecological Justice; Routledge: London, UK; New York, NY, USA, 2005.

32. Taylor, P.W. The ethics of respect for nature. Environ. Ethics 1981, 3, 197-218. [CrossRef]

33. Rowe, S.J. Ecocentrism: The chord that harmonizes humans and earth. Trumpeter 1994, 11, 106-107.

34. Meadows, D.H.; Meadows, D.L.; Randers, J.; Behrens, W.W., III. The Limits to Growth; Universe Books: New York, NY, USA, 1972.

35. Kramer, M.; Agarwal, R.; Srinivas, A. Business as Usual Will Not Save the Planet. Harv. Bus. Rev. 2019, 12. Available online: https://hbr.org/2019/06/business-as-usual-will-not-save-the-planet (accessed on 20 September 2020).

36. Kallis, G. In defense of degrowth. Ecol. Econ. 2011, 70, 873-880. [CrossRef]

37. Crist, E. Abundant Earth and population. In Life on the Brink: Environmentalists Confront Overpopulation; Cafaro, P., Crist, E., Eds.; University of Georgia Press: Athens, GA, USA, 2012; pp. 141-153.

38. Wijkman, A.; Rockström, J. Bankrupting Nature: Denying Our Planetary Boundaries; Routledge: New York, NY, USA, 2012.

39. Washington, H.; Maloney, M. The need for ecological ethics in new ecological economics. Ecol. Econ. 2020, 169, 106478. [CrossRef]

40. Blicharska, M.; Smithers, R.J.; Mikusiński, G.; Rönnbäck, P.; Harrison, P.A.; Nilsson, M.; Sutherland, W.J. Biodiversity's contributions to sustainable development. Nat. Sustain. 2019, 2, 1083-1093. [CrossRef]

41. Garnett, T.; Appleby, M.C.; Balmford, A.; Bateman, I.J.; Benton, T.G.; Herrero, M. Sustainable intensification in agriculture: Premises and policies. Science 2013, 341, 33-34. [CrossRef]

42. The Economist. Business Principles Charities Are Becoming More Professional, 30 September 2017. Available online: https://www.economist.com/international/2017/09/30/charities-are-becoming-more-professional (accessed on 20 September 2020). 
43. Cohen, S. States of Denial: Knowing About Atrocities and Suffering; Polity Press: Cambridge, UK, 2001.

44. Kopnina, H.; Blewitt, J. Sustainable Business: Key Issues, 2nd ed.; Routledge: New York, NY, USA, 2018.

(C) 2020 by the author. Licensee MDPI, Basel, Switzerland. This article is an open access article distributed under the terms and conditions of the Creative Commons Attribution (CC BY) license (http://creativecommons.org/licenses/by/4.0/). 